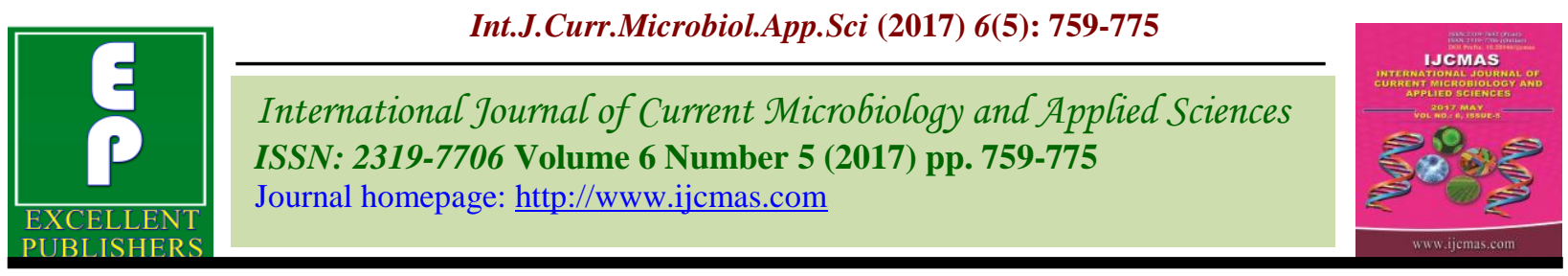

Original Research Article

https://doi.org/10.20546/ijcmas.2017.605.086

\title{
Correlation Studies on Association of Morphological and Biochemical Traits for Potato Apical Leaf-Curl Disease Resistance or Susceptibility
}

\author{
Devashri Maan* A.K. Bhatia and Mandeep Rathi ${ }^{1}$ \\ Department of Vegetable Science, ${ }^{1}$ Department of Entomology, CCS Haryana Agricultural \\ University, Hisar-125004, Haryana, India \\ *Corresponding author
}

\section{A B S T R A C T}

\section{Keywords}

Potato, apical leaf curl disease, heritability, genetic advance, correlation coefficient.

\section{Article Info}

Accepted: 04 April 2017 Available Online: 10 May 2017
High phenotypic coefficient of variation and genotypic coefficient of variation were observed for percent potato apical leaf-curl disease (PALCD) incidence at 40, 60 and 80 DAP, whitefly population at 20 and 30 DAE and phenols. High heritability (broad sense) along with genetic advance as per cent of mean was found in plant height at $60 \mathrm{DAP}$, per cent PALCD incidence at 40,60 and 80 DAP, whitefly population at 20,30 and 40 DAE, phenols, number of stomata per leaf, foliage senescence at harvest, plant vigour at 60 DAP and total yield, indicating simple selection method for the improvement of these traits. Correlation studies revealed that per cent PALCD incidence was found significantly and positively associated with whitefly population and number of stomata per leaf, which indicates that for improving disease resistance, selection should be made for those lines, which have less number of whitefly and number of stomata. The per cent PALCD incidence was significant and negatively associated with plant height, plant vigour, weight of stem per hill, weight of leaves per hill, weight of foliage per hill, leaf area index, total yield, marketable yield, harvest index and phenols which suggests that for potato apical leaf-curl disease resistance, selection should be made on the basis of high values of these characters. Path analysis indicated that the per cent PALCD incidence had positive and highest contribution (1.941) towards plant height at 60 days after planting. Highest indirect contribution was exhibited by plant vigour at 60 days after planting (-0.032) Low population of whitefly, less number of stomata and high phenols were the main characters contributed towards potato apical leaf curl disease resistance.

\section{Introduction}

Potato (Solanum tuberosum L.) is one of the most important vegetable crops and ranks third among food crops after rice and wheat in India and worldwide from human consumption point of view. India is the $3^{\text {rd }}$ largest producer of potato in world after China and Russia. During 2010-11, this crop was grown on 18.30 lakh hectares with a production of 36.57 million tonnes (Anonymous, 2011a).
Potato is also an important vegetable crop of Haryana. Haryana ranks first in production and second in area among vegetable crops. In 2010-11, the area and production of potato were 26780 hectares and 598164 tones, respectively (Anonymous, 2011b). The productivity of potato crop in the state is quite lower $(22.33 \mathrm{t} / \mathrm{ha})$ than the potential yield. Potato crop is attacked by many diseases, which are widely spread and other, which 
affect the crop growth and production, are localized. Garg et al., (2001) reported that potato plants infected with apical leaf curl virus showed chlorotic blotching, crinkling, mosaic, apical leaf-curling and stunting. In Haryana state, the sporadic incidence of PALCD was observed first time in early October planted crop at Hisar during December 1996 and subsequently it spread to other parts. Severe yield losses due to this disease have been reported in potato by Lakra (2002). Annual loss due to potato viruses with an average of $30-40 \%$ incidence is about 25$30 \%$ yield reduction (Khurana, 1999).

Lakra, 2002 also reported that with 100 per cent disease incidence of PALCV, more than 50 per cent losses in yield has been reported in early sown potato cultivar Kufri Ashoka. The most deleterious effect was observed on reduction in leaf area, chlorophyll content, plant height, number of tubers per plant and weight of tubers per plant (Lakra, 2003a).

The genetic resistance is more safe, stable and economical in comparison to pesticide use. The pre-requisite for the development of disease resistant varieties is the availability of efficient and reliable screening techniques and the identification of resistant sources. Some of the biochemical and morphological attributes, which act as a defense mechanism in the host plant against insects and diseases, are also of considerable importance.

The biochemical reaction leading to susceptibility or resistance can be helpful in the screening germplasm at early stage against potato apical leaf curl disease in potato. Therefore, in view of the importance of crop and disease, the present investigation was planned to study the correlation of morphological and biochemical attributes of potato hybrids to justify their role in resistance or susceptibility to potato apical leaf curl disease (PALCD).

\section{Materials and Methods}

Studies were conducted at Research Area, Department of Vegetable Science, CCS Haryana Agricultural University, Hisar during winter (Rabi) season of 2012-13. Eight genotypes/varieties viz., Kufri Bahar, Kufri Pushkar, Kufri Surya, Kufri Pukhraj, Kufri Khyati, Kufri Sadabahar, Kufri Badshah and CP 1588 were evaluated. During the course of experiments, ten potato plants were selected at random in each replication and treatment and observations were recorded for the following parameters:

\section{Growth parameters}

The studied growth parameters included per cent plant emergence, plant height $(\mathrm{cm})$ (at 45, 60, 75 and 90 DAP), number of stems per hill, number of leaves per hill, weight of leaves per hill $(\mathrm{g})$, weight of stem per hill $(\mathrm{g})$, Leaf area index (LAI), weight of foliage (g), number of stomata per leaf, plant vigour (at 60 DAP) and foliage senescence at harvest.

\section{Tuber yield parameters}

Total tuber yield (q/ha), marketable tuber yield (q/ha) and harvest index were calculated for all the genotypes and subjected to further studies to estimate variances, heritability and genetic advance.

\section{Whitefly population and incidence of PALCD incidence}

Whitefly population was counted on three plants from each plot. Number of whitefly was counted on three compound leaves at different positions, i.e., bottom, middle and top of the plant and then worked out whitefly per leaf. Number of plants showing apical leaf curl symptoms were counted in each plot/genotype and percent disease incidence was calculated as below: 
No. of plants effected with apical leaf curl disease per plot

Apical leaf curl disease $(\%)=\frac{\text { Total number of plants per plot }}{\mathrm{x}} \mathrm{x}$

The experiment was conducted in randomized block design. The data related to different characters were analyzed statistically by applying the Analysis of Variance Technique as suggested by Panse and Sukhatme (1957) and subjected to correlation and pathcoefficient analysis studies.

\section{Correlation studies for ascertaining the association of morphological and biochemical traits for PALCD resistance or susceptibility}

\section{Parameters of variability}

Mean $(\overline{\mathrm{X}})$

The mean value of each character was worked out by dividing the total values by corresponding number of observations

\section{Variance $\left(\sigma^{2}\right)$}

The variance is the measure of variability and is defined as the average of the squared deviation from the mean. The genetic variance was arrived at by deducting the variance of control plants from the total variance of the population.

\section{Coefficient of variation $(\sigma)$ :}

Genotypic and phenotypic coefficients of variation were estimated by the formula suggested by Burton (1952) for each character as:

Phenotypic coefficient of variation (P.C.V.) $=$ $\sqrt{\frac{\sigma^{2} \mathrm{pii}}{\overline{\mathrm{X}}}} \times 100$
Genotypic coefficient of variation (G.C.V.) = $\sqrt{\frac{\sigma^{2} \text { gii }}{\bar{X}}} x 100$

Where, $x$ is the mean of that particular/specific character

\section{Heritability (in broad sense)}

Heritability (\%) in broad sense was calculated according to the formula suggested by Hanson et al., (1956) for each character.

$\mathrm{h}^{2}(\mathrm{bs})=\sqrt{\frac{\sigma \mathrm{gij}{ }^{2}}{\sigma \mathrm{pij}^{2}}} \times 100$

\section{Genetic advance expressed as percentage of mean}

Estimates of appropriate variance components were substituted for the parameters expected genetic gain as suggested by Lush (1949) and Johnson et al., (1955). The expected genetic advance was calculated at 5\% selection intensity for each character as:

Genetic advance $(\%$ of mean $)=\frac{\sigma \mathrm{pKH}}{\overline{\mathrm{X}}} \times 100$

Where, $\mathrm{K}$ is the selection differential expressed in terms of phenotypic standard variations. Using 5\% selection in a large sample from a normally and independent distributed population, the value of selection intensity (K) is equal to 2.06 (Allard, 1960).

$\mathrm{H}=$ Heritability in broad sense

$\overline{\mathrm{X}}=$ Mean value for that character over all the genotypes 


\section{Correlation coefficient analysis}

Phenotypic ' $\mathrm{r}(\mathrm{P})$ ' and genotypic ' $\mathrm{r}(\mathrm{g})$ ' correlation coefficients for all possible pairs of 10 characters were calculated from the variance and covariance's according to Johnson et al., (1955). The genotypic correlation was estimated by $\mathrm{r}(\mathrm{g})=\sigma \mathrm{x}$ y $(\mathrm{g}) /[\square \sigma \mathrm{x}(\mathrm{g}) \mathrm{X} \sigma \mathrm{y}(\mathrm{g})]$.

Where, $\sigma$ x y $(\mathrm{g})=$ Genotypic covariance between characters $\mathrm{x}$ and $\mathrm{y}$

$\sigma \mathrm{x}(\mathrm{g})=$ Genotypic variance of character $\mathrm{x}$

$\sigma^{2} \mathrm{y}(\mathrm{g})=$ Genotypic variance of character $\mathrm{y}$

The phenotypic correlation was measured by $\mathrm{r}(\mathrm{P})=\sigma \mathrm{x} \mathrm{y}(\mathrm{P}) /[\square \sigma \mathrm{x}(\mathrm{P}) \sigma \mathrm{y}(\mathrm{P})]$

Where,

$\sigma \times \mathrm{y}(\mathrm{P})=$ Phenotypic covariance between characters $\mathrm{x}$ and $\mathrm{y}$

$\sigma^{2} \mathrm{x}(\mathrm{P})=$ Phenotypic variance of character $\mathrm{X}$

$\sigma^{2} \mathrm{y}(\mathrm{P}) \quad=$ Phenotypic variance of character $\mathrm{y}$

\section{Path-coefficient analysis}

The genotypic correlation coefficients were used to work out path coefficient analysis. Path coefficient matrix was obtained according to Dewey and Lu (1959). A set of simultaneous equations in the following form were solved:

$\mathrm{ri}_{\mathrm{y}}=\mathrm{P}_{\mathrm{iy}}+\operatorname{rij}_{2 \mathrm{y}}+\ldots \ldots \ldots \ldots \ldots \ldots \ldots \ldots \mathrm{r}_{\mathrm{nx}} \mathrm{P}_{\mathrm{xy}}$

Where,

$\mathrm{r}_{\mathrm{ny}}=$ Correlation coefficient of one character and yield
$\mathrm{P}_{\mathrm{ny}}=$ Path coefficient between the character and yield

$r_{n 2} r_{n 3} \ldots . . r_{n x}=$ represent correlation coefficient between that character and each of other yield components in turn.

Path coefficients $\mathrm{P}_{\mathrm{jy}}$ were obtained as follows: $\mathrm{P}_{\mathrm{jy}}=\left(\mathrm{B}^{-1}\right) \times \mathrm{A}$

The indirect effects for a particular character through other characters were obtained by multiplication of direct Path and particular correlation coefficient between those characters, respectively.

Indirect effect $=r_{i j} \times P_{j y}$

Where,

$\mathrm{i}=1 \ldots \ldots \ldots \ldots \ldots \ldots \ldots \ldots \ldots \ldots$

$\mathrm{j}=1 \ldots \ldots \ldots \ldots \ldots \ldots \ldots \ldots \ldots \ldots$

$\mathrm{P}_{\mathrm{jy}}=\mathrm{P}_{1 \mathrm{y}} \mathrm{P}_{2 \mathrm{y}} \ldots \ldots \ldots \ldots \ldots \ldots \ldots \ldots \ldots . . \mathrm{P}_{\mathrm{ny}}$

The residual factors i.e. the variation in yield unaccounted for those associated was calculated from the following formulae:

Residual factor $(\mathrm{x})=1-\mathrm{R}^{2}$

Where,

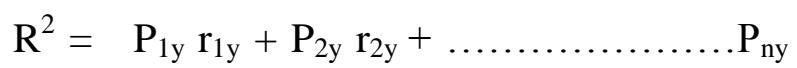

$\mathrm{R}^{2}$, is squared multiple correlation coefficients and is the amount of variation in yield that can be accounted for by the yield component character.

Path coefficient analysis was determined as per method suggested by Dewey and Lu (1959).

\section{Results and Discussion}

Correlation coefficient analysis measures the mutual relationship between various 
characters and determines the components on which selection can based for improvement. Knowledge of correlation that exists among important characters may facilitate proper interpretation of results and provides a basis for planning efficient breeding programmes. The extent of observed relationship between two characters is known as phenotypic correlation. Genotypic correlation, on the other hand, is the inherent association between two characters (Harland, 1939). A path coefficient is simply a standardized partial regression coefficient and as such measures the direct influence of one variable upon another and permits the separation of the correlation coefficients into components of direct and indirect effects. The results based on above analytic studies are presented and discussed in detail below.

Estimates of Variances, Heritability and Genetic Advance for Various Growth, Yield and Biochemical Characters in Potato

Estimates of variances, heritability and genetic advance for various growth, yield and biochemical characters in potato are presented in Table 1.

\section{Growth parameters}

\section{Per cent plant emergence 30 DAP}

Phenotypic (7.46\%) and genotypic (8.14\%) coefficients of variance were found very low. However, heritability was found very high $(84.11 \%)$ and genetic advance as per cent of mean was low (14.10\%).

\section{Plant height}

In case of 45 DAP, phenotypic and genotypic covariance were 24.56 and $24.40 \%$, respectively while heritability was very high (98.87\%) and genetic advance was $49.69 \%$.
Plant height at 60 DAP showed phenotypic $(21.66 \%)$ and genotypic coefficients of variance $(21.56 \%)$. The heritability in broad sense was found very high $(99.12 \%)$, however, the genetic advance was $44.23 \%$. Phenotypic and genotypic covariance was 19.64 and $19.67 \%$, respectively, for plant height 75 DAP. The heritability for plant height at 75 days was recorded very high (99.62\%) and genetic advance was $40.38 \%$. When observed for plant height 90 DAP, phenotypic and genotypic coefficients of variance were 19.59 and $19.66 \%$, respectively. The heritability was found very high (99.33\%) and genetic advance was $40.23 \%$.

\section{Plant vigour at 60 DAP}

Phenotypic and genotypic coefficients of variance found 32.72 and $35.92 \%$, respectively. Heritability was found $83.02 \%$ and genetic advance was $61.43 \%$.

\section{Number of stems per hill}

Phenotypic and genotypic coefficients of variance were observed 27.47 and $28.73 \%$, respectively. Heritability was recorded $91.44 \%$, while genetic advance was high $54.12 \%$.

\section{Number of leaves per hill}

Phenotypic and genotypic coefficients of variance was found 18.30 and $23.99 \%$, respectively heritability was found low $(58.21 \%)$ and genetic advance was found low $28.77 \%$.

\section{Weight of stem per hill}

Phenotypic and genotypic coefficients of variance observed 15.73 and $24.47 \%$, respectively. Heritability in broad sense was found minimum in growth parameters 
(41.35\%) and genetic advance found very low $(20.84 \%)$.

\section{Weight of leaves per hill}

Phenotypic and genotypic coefficients of variance were found 33.63 and $33.63 \%$, respectively. Heritability was observed $46.89 \%$ while genetic advance was found $32.49 \%$.

\section{Weight of foliage per hill}

Phenotypic and genotypic coefficients of variance were observed 24.44 and $20.19 \%$, respectively. Heritability and genetic advance were recorded 68.24 and $34.36 \%$, respectively.

\section{Leaf area index}

Phenotypic and genotypic coefficients of variance were found 26.41 and $24.60 \%$, respectively, while high heritability $(86.84 \%)$ was recorded for this character. Genetic advance was found $47.19 \%$.

\section{Number of stomata per leaf}

Phenotypic and genotypic coefficients of variance was found 44.12 and $40.73 \%$, heritability was $85.22 \%$ and genetic advance was found high $(77.46 \%)$

\section{Foliage senescence at harvest}

Phenotypic and genotypic coefficients of variance were found 26.52 and $26.21 \%$, respectively. Heritability was found high (97.67\%). Genetic advance was recorded $53.12 \%$.

Likewise, Ara et al., (2009) observed high estimates of coefficients of variability, heritability and genetic gain (GA\%) for fresh weight per plant, number of main shoot and fresh weight of tubers per plant indicates that these characters are largely controlled by additive gene action and that straight selection for them would be effective.

\section{Tuber yield parameters}

\section{Total tuber yield}

Phenotypic and genotypic coefficients of variance were found 28.97 and $27.33 \%$, respectively. High heritability was recorded for total yield, which was $88.99 \%$ while genetic advance as percent of mean was found $53.12 \%$.

\section{Marketable yield}

Phenotypic and genotypic coefficients of variance were found 28.99 and $26.92 \%$, respectively. Heritability was found $86.25 \%$ and genetic advance as percent of mean was found $51.51 \%$.

\section{Harvest index}

Phenotypic and genotypic coefficients of variance were found very low (10.59 and $9.55 \%)$, heritability was found high $(81.33 \%)$ and genetic advance as percent of mean was very low $(17.75 \%)$.

\section{Phenols}

Phenol content in the plant determines the resistance to the disease. Phenotypic and genotypic coefficients of variance were found 50.77 and $50.18 \%$, respectively. Heritability was found $97.71 \%$ and genetic advance as percent of mean was found very high $(102.19 \%)$.

Similar results were reported by Bhardwaj et al., (2005) for yield per plant. Mondal (2003) also reported high heritability and genetic advance as percent of mean higher genotypic 
and phenotypic coefficients of variance for average in potato. Khayatnezhad et al., (2011) observed high heritability for tuber fresh weight at 90 days and plant height at 50 days suggested that selection for these characters will be effective and improvement is could be possible made though phenotypic selection. Sattar et al., (2007) observed high heritability coupled with high genetic advance as percent of mean for number of potato tubers per plant, yield per plant and average weight of a tuber suggesting selection for these traits would give good response.

Estimates of Variances, Heritability and Genetic Advance for Whitefly Population and Per Cent PALCD

Whitefly population and incidence of PALCD incidence

Estimates of variances, heritability and genetic advance for whitefly population and per cent apical leaf curl disease incidence in potato are presented in Table 2.

\section{Whitefly population at 20, 30 and 40 DAE}

Phenotypic and genotypic coefficients of variance were found 83.61 and $82.68 \%$, respectively. High heritability $(97.79 \%)$ and genetic advance (168.43\%) were observed at 20 DAE. After 30 DAE all the parameters like phenotypic and genotypic coefficients of variance, heritability and genetic advance were found high $(99.30 \%, 96.52 \%, 94.47 \%$ and $193.26 \%$, respectively). High phenotypic $(51.19 \%)$ and genotypic coefficient of variance $(46.53 \%)$ were recorded for whitefly population at 30 days after emergence the heritability was found $82.61 \%$ and genetic advance was observed $87.12 \%$.

\section{Per cent PALCD incidence}

At 40 DAP, phenotypic and genotypic coefficients of variance were found high which was 150.22 and $149.16 \%$, respectively. Similarly heritability was observed $98.59 \%$ and genetic advance was recorded very high $305.09 \%$. Phenotypic and genotypic coefficients of variance were found high (95.47\% and $95.17 \%)$. Heritability was found high $(95.47 \%)$ and genetic advance was also high $(191.57 \%)$ at 60 DAP. The data presented in Table 1 also showed that phenotypic and genotypic coefficients of variance were found high (79.90 and $79.43 \%$ ), heritability was recorded high $(98.81 \%)$ and genetic advance was also high $(102.19 \%)$.

\section{Correlation Studies for Ascertaining the} Association of Morphological and Biochemical Traits for PALCD Resistance or Susceptibility

In order to know the association between disease and other attributes, genotypic and phenotypic correlation coefficients were estimated which are presented in Table 3 and 4. In general, the magnitude of correlation coefficients at genotypic level was found higher than their corresponding correlations at phenotypic level.

\section{Growth parameters}

The analysis of genotypic correlation showed that percent plant emergence at 30 DAP was significantly positive correlated with plant vigor at 60 DAP (0.460), foliage senescence (0.432), total tuber yield (0 .717), marketable yield (0.661), harvest index (0.854) and phenols (0.552). However it was significant negatively correlated with number of stomata (-0.752), whitefly population at 20 DAE ($0.533)$, whitefly population at 30 DAE (0.593 ), whitefly population at 40 DAE ($0.425)$, per cent PALCD at 40 DAP (0-.558), per cent PALCD at 60 DAP (0-.453), per cent PALCD at 80 DAP (0-.416). 
Plant height at 45 DAP was significantly positively correlated with plant height at 60 DAP (0.988), plant height at 75 DAP (0.997), plant height at 90 DAP (0.976) and plant vigor at 60 DAP (0.549), no. of leaves per hill (0.806), weight of stem per hill (0.185), weight of leaves per hill (0.745), weight of foliage per hill (0.941), leaf area index $(0.502)$, foliage senescence at harvest $(0.740)$.

Plant height at 60 DAP showed significantly positively correlated with plant height at 75 DAP (0.997), plant height at 90 DAP (0.990), plant vigor at 60 DAP (0.529), number of leaves (0.802), weight of stem (0.190), weight of leaves (0.731), weight of foliage (0.921), leaf area index (0.564) and foliage senescence (0.808). Plant height at 75 DAP exhibited significantly positively correlated with plant height at 90 DAP (0.985), plant vigor at 60 DAP (0.507), number of leaves per hill (0.834), number of stem per hill (0.192), weight of leaves per hill (0.734), weight of foliage per hill (0.938), leaf area index (0.502), foliage senescence at harvest (0.789). Plant height at 90 DAP was found significantly positive correlation with plant vigor at 60 DAP (0.565), number of leaves per hill (0.885), weight of stem per hill (0.185), weight of leaves per hill (0.822), weight of foliage per hill (0.969), leaf area index (0.593), foliage senescence at harvest (0.792), marketable yield (0.414).

Plant vigor at 60 DAP had significantly positive correlated with weight of stem per hill (0.472), weight of leaves per hill (0.912), weight of foliage per hill (0.740), leaf area index (0.872), total yield (0.922), marketable yield (0.995), harvest index (0.516) and phenols (0.834), however it was negatively significant associated with number of stomata (-0.774), whitefly population at 20 DAE (0.930), whitefly population at 30 DAE (0.945), whitefly population at 40 DAE (0.906), percent PALCD at 40 DAP (-0.935), per cent PALCD at 60 DAP (-0.951) and per cent PALCD at 80 DAP (-0.920).

Number of stem per hill had significantly positively correlation with number of leaves per hill (0.413), leaf area index (0.507), total yield (0.423), however it was negatively significant correlated with whitefly population at 20 DAE (-0.435), whitefly population at 30 DAE (-0.444), whitefly population at 40 DAE $(-0.461)$.

Number of leaves per hill was significantly positive correlated with weight of stem per hill (0.814), weight of leaves per hill (0.796), weight of foliage per hill (0.829), leaf area index (0.493), number of stomata (.494), foliage senescence at harvest (0.479), however it was negatively significant with harvest index (-0.820).

Weight of stem per hill was significantly and positively correlated with weight of leaves per hill (0.784), weight of foliage per hill (0.980), leaf area index (0.605), foliage senescence at harvest (0.442), total yield (0.414) and marketable yield (0.442). Weight of leaves per hill significantly positive correlated with weight of foliage per hill (0.934), leaf area index (0.948), foliage senescence at harvest $(0.415)$, total yield (0.569), marketable yield (0.643) and phenols (0.730), however it was negatively significant with per cent PALCD at 80 DAP (-0.902), per cent PALCD at 60 DAP (-0.819), per cent PALCD at 40 DAP ($0.649)$, whitefly population at 20 DAE (0.737), whitefly population at 30 DAE (0.728 ) and whitefly population at 40 DAE (0.843). Weight of foliage per hill had significantly positive correlation with leaf area index $(0.711)$, foliage senescence at harvest (0.670), total yield (0.670), marketable yield (0.502), harvest index (0.548) and phenols (0.520), however it was negatively significant with per cent PALCD at 80 DAP (-0.620), per cent PALCD at 60 
DAP (-0.565), per cent PALCD at 40 DAP ($0.474)$, whitefly population at 20 DAE (0.503 ), whitefly population at 30 DAE ($0.501)$ and whitefly population at 40 DAE (0.538).

Leaf area index was significantly positively correlated with foliage senescence at harvest (0.473), total yield (0.658), marketable yield (0.746) and phenols (0.765), however it was negatively significantly associated with per cent PALCD at 80 DAP (-0.890), per cent PALCD at 60 DAP (-0.883), per cent PALCD at 40 DAP (-0.801), whitefly population at 20 DAE (-0.915), whitefly population at 30 DAE (-.0917) and whitefly population at 40 DAE ($0.931)$.

Number of stomata per leaf had significantly positive correlation with per cent PALCD at 40 DAP (0.936), per cent PALCD at 60 DAP (0.775), per cent PALCD at 40 DAP (0.677), whitefly population at 20 DAE (0.740), whitefly population at $30 \mathrm{DAE}(0.795)$ and whitefly population at 40 DAE (0.634), however it was negatively and significantly associated with total yield (-0.763). Marketable yield (-0.820) and harvest index (0.970). Borah and Bordoloi (1998) reported similar results for tomato leaf curl virus and whitefly population.

\section{Tuber yield parameters}

Total yield was significantly and positively correlated with marketable yield (0.993), harvest index (0.730) and phenols (0.666), however it was negatively significant with per cent PALCD at 40 DAP (-0.783), per cent PALCD at 60 DAP (-0.742), per cent PALCD at 80 DAP (-.730), whitefly population at 20 DAE (-.829), whitefly population at $30 \mathrm{DAE}$ $(-0.865)$ and whitefly population at 40 DAE (0.725). Marketable yield was significantly and positive correlated with harvest index (0.697) and phenols (0.759), however it was negatively and significant correlated with per cent PALCD at 40 DAP (-0.869), per cent PALCD at 60 DAP (-0.850), per cent PALCD at 80 DAP (-0.831), whitefly population at 20 DAE (-0.902), whitefly population at $30 \mathrm{DAE}$ $(-0.932)$ and whitefly population at 40 DAE ($0.835)$.

Harvest index had significantly positive correlation with phenols (0.508), however it was negatively significantly correlated with per cent PALCD at 40 DAP (-0.706), per cent PALCD at 60 DAP (-0.523), per cent PALCD at 80 DAP (-0.410), whitefly population at 20 DAE (-0.559), whitefly population at $30 \mathrm{DAE}$ $(-0.607)$ and whitefly population at 40 DAE (0.410). Similar result was found by Som (1973) for phenolic compounds in tomato.

Sattar et al., (2007) observed high genotypic coefficients of variation for number of potato tubers per plant, yield per plant and average weight of a tuber suggesting selection for these traits would give good response. Khayatnezhad et al., (2011) found significant positive correlations between starch content and dry matter content.

Stronger positive correlations were found between tuber yield and main stems per plant $(\mathrm{r}=0.925)$, plant tuber weight $(\mathrm{r}=0.992)$, plant height $(\mathrm{r}=0.843)$. Similarly, Ara et al., (2009) reported that potato yield per plant had a significant positive correlation with plant height, number of leaves per plant and fresh weight per plant depicted that the characters, namely tuber fresh weight per plant have high and positively correlatively towards yield per plant and could be considered as selection criteria in potato breeding programme.

\section{Whitefly population and incidence of} PALCD incidence

Whitefly population at 20 DAE had significantly positive correlated with per cent 
PALCD at 40 DAP (0.884), per cent PALCD at 60 DAP (0.966), per cent PALCD at 80 DAP (.959), whitefly population at 30 DAE (1.002) and whitefly population at $40 \mathrm{DAE}$ (1.009) while it was negatively and significant correlated with phenols (-0.889). Whitefly population at 30 DAE had significantly positive correlated with per cent PALCD at 40 DAP (0.912), per cent PALCD at 60 DAP (0.968), per cent PALCD at 80 DAP (0.952), and whitefly population at 40 DAE (1.001) and showed negatively significant correlation with phenols (-0.888).

Whitefly population at 40 DAE had significantly positive correlation with per cent PALCD at 40 DAP (0.841), per cent PALCD at 60 DAP (0.985), per cent PALCD at 80 DAP (1.007), it was negatively significant correlated with phenols (-0.940). Borah and Bordoloi (1998) reported similar results for tomato leaf curl virus and whitefly population.

Percent PALCD at 40 DAP exhibited significantly positive correlated with per cent PALCD at 60 DAP (0.942), per cent PALCD at 80 DAP (0.860) it was negatively significant with phenols (-0.851). Percent PALCD at 60 DAP also showed significantly positive correlation with per cent PALCD at 80 DAP (0.986) and was negatively significantly correlated with phenols (-0.947). However, percent PALCD at 80 DAP had significantly negative correlation with phenols (-.947).

The remaining characters showed nonsignificant correlation hence not explained.

\section{Path Coefficient Analysis}

In the present study, path coefficient using percent apical leaf-curl disease incidence as dependent character and remaining 23 characters as independent variables was worked out. Percent PALCD incidence was chosen as dependent variable because it directly affects tuber yield severely. Path coefficient analysis was used to partition the genotypic correlation coefficient of 23 characters studied with per cent PALCD incidence into direct and indirect effects.

Since correlation studies alone are not adequate to establish a clear relationship among the characters, so the assessment of real contribution of individual character towards the disease incidence becomes essential. The direct and indirect effects of various characters along with their genotypic correlation coefficients with PALCD incidence per plant are presented in Table 5.

\section{Direct Effect}

At the genotypic level plant height at 60 DAP (1.941) had the highest direct positive effect on per cent PALCD at 80 DAP followed by plant height at 45 DAP (1.856), number of stomata (0.913), number of stem per hill (0. 812), plant height at 75 DAP (0.786) and whitefly population at $30 \mathrm{DAE}(0.508)$.

\section{Indirect Effect}

However plant vigour at 60 DAP (-0.032), number of leaves per hill (-0.686), weight of foliage per hill (-0.762), marketable yield ($0.219)$, harvest index (-0.064), whitefly population at $20 \mathrm{DAE}(-0.542)$ and per cent PALCD at 60 DAP $(-1.855)$ had the negative direct effect on per cent PALCD at 80 DAP. Similar results were found by Bhullar et al., (1974) for phenolic compounds. Compared to the simple correlation analysis, path analysis of tuber yield and its traits demonstrated that plant height, medium tuber weight and big tuber weight evolved the highest direct influence, 2.19, 0.867 and 0.656, respectively (Khayatnezhad et al., 2011). 
Table.1 Estimates of variances, heritability and genetic advance for various characters in potato

\begin{tabular}{|c|c|c|c|c|c|c|c|c|}
\hline Characters & Mean & Range & GV & $\mathbf{P V}$ & $\begin{array}{c}\text { GCV } \\
(\%)\end{array}$ & $\begin{array}{c}\text { PCV } \\
(\%)\end{array}$ & $\begin{array}{c}\text { Heritabil } \\
\text { ity } \\
(\%)\end{array}$ & $\begin{array}{c}\text { Genetic advance } \\
\text { as percent of } \\
\text { Mean }\end{array}$ \\
\hline Per cent plant emergence at 30 DAP & 90.25 & $76.66-96.11$ & 45.43 & 54.02 & 7.46 & 8.14 & 84.11 & 14.10 \\
\hline Plant height at 45 DAP & 37.69 & $26.84-57.77$ & 83.66 & 84.62 & 24.26 & 24.40 & 98.87 & 49.69 \\
\hline Plant height at60 DAP & 48.30 & $37.68-72.70$ & 108.54 & 109.50 & 21.56 & 21.66 & 99.12 & 44.23 \\
\hline Plant height at 75 DAP & 55.57 & $43.87-80.42$ & 119.12 & 119.58 & 19.64 & 19.67 & 99.62 & 40.38 \\
\hline Plant height at 90 DAP & 60.54 & $48.73-87.94$ & 140.80 & 141.75 & 19.59 & 19.66 & 99.33 & 40.23 \\
\hline Plant vigour at 60 DAP & 2.70 & $1.33-3.66$ & 0.78 & 0.94 & 32.72 & 35.92 & 83.02 & 61.43 \\
\hline Number of stem per hill & 32.62 & $1.90-4.90$ & 80.63 & 87.88 & 27.47 & 28.73 & 91.44 & 54.12 \\
\hline Number of leaves per hill & 529.25 & $38.36-69.66$ & 9386.00 & 16123.77 & 18.30 & 23.99 & 58.21 & 28.77 \\
\hline Weight of stem per hill & 1173.33 & $96.33-169.00$ & 0.03 & 0.08 & 15.73 & 24.47 & 41.35 & 20.84 \\
\hline Weight of leaves per hill & 1386.25 & $72.00-184.33$ & 101961.90 & 217413.69 & 23.04 & 33.63 & 46.89 & 32.49 \\
\hline Weight of foliage per hill & 2532.50 & $168.33-353.33$ & 0.26 & 0.38 & 20.19 & 24.44 & 68.24 & 34.36 \\
\hline Leaf area index & 1.38 & $0.96-1.85$ & 0.11 & 0.13 & 24.60 & 26.41 & 86.74 & 47.19 \\
\hline Number of stomata & 3.75 & $2.33-7.33$ & 2.33 & 2.73 & 40.73 & 44.12 & 85.22 & 77.46 \\
\hline Foliage senescence at harvest & 2.67 & $2.16-4.18$ & 0.48 & 0.50 & 26.21 & 26.52 & 97.67 & 53.36 \\
\hline Total yield & 316.66 & $155.46-426.24$ & 38.85 & 43.65 & 27.33 & 28.97 & 88.99 & 53.12 \\
\hline Marketable yield & 297.84 & $148.22-426.24$ & 33.34 & 38.66 & 26.92 & 28.99 & 86.25 & 51.51 \\
\hline Harvest index & 63.79 & $49.05-68.91$ & 37.17 & 45.70 & 9.55 & 10.59 & 81.33 & 17.75 \\
\hline Phenol & 34.80 & $10.05-62.53$ & 305.09 & 312.23 & 50.18 & 50.77 & 97.71 & 102.19 \\
\hline
\end{tabular}


Table.2 Estimates of variances, heritability and genetic advance for whitefly population and per cent apical leaf curl disease incidence in potato

\begin{tabular}{|l|c|c|c|c|c|c|c|c|}
\hline \multicolumn{1}{|c|}{ Characters } & Mean & Range & GV & PV & GCV & $\begin{array}{c}\text { PCV } \\
(\%)\end{array}$ & $\begin{array}{c}\text { Heritability } \\
(\%)\end{array}$ & $\begin{array}{c}\text { Genetic advance } \\
\text { as percent of Mean }\end{array}$ \\
\hline Whitefly population at 20 DAE & 49.41 & $10.00-75.66$ & 1669.64 & 1707.45 & 82.68 & 83.61 & 97.79 & 168.43 \\
\hline Whitefly population at 30 DAE & 29.25 & $2.33-79.33$ & 797.11 & 843.73 & 96.52 & 99.30 & 94.47 & 193.26 \\
\hline Whitefly population at 40 DAE & 4.29 & $1.33-14.00$ & 3.98 & 4.82 & 46.53 & 51.19 & 82.61 & 87.12 \\
\hline Per cent PALCD at 40 DAE & 16.25 & $3.66-35.66$ & 587.50 & 595.91 & 149.16 & 150.22 & 98.59 & 305.09 \\
\hline Per cent PALCD at 60 DAE & 36.25 & $6.66-69.33$ & 1190.35 & 1246.78 & 95.17 & 97.40 & 95.47 & 191.57 \\
\hline Per cent PALCD at 60 DAE & 50.29 & $9.33-100$ & 1595.91 & 1615.06 & 79.43 & 79.90 & 98.81 & 162.66 \\
\hline
\end{tabular}


Table.3 Genotypic correlation coefficient among different characters in potato

\begin{tabular}{|c|c|c|c|c|c|c|c|c|c|c|c|c|c|c|c|c|c|c|c|c|c|c|c|c|}
\hline $\begin{array}{c}\text { Genotypic } \\
\text { correlation }\end{array}$ & \begin{tabular}{|c|} 
Character \\
1
\end{tabular} & $\begin{array}{c}\text { Character } \\
2\end{array}$ & $\begin{array}{c}\text { Character } \\
3\end{array}$ & $\begin{array}{c}\text { Character } \\
4\end{array}$ & $\begin{array}{c}\text { Character } \\
5\end{array}$ & $\begin{array}{c}\text { Character } \\
6\end{array}$ & $\begin{array}{c}\text { Character } \\
7\end{array}$ & \begin{tabular}{|c|} 
Character \\
8
\end{tabular} & $\begin{array}{c}\text { Character } \\
9\end{array}$ & \begin{tabular}{|c|} 
Character \\
10
\end{tabular} & \begin{tabular}{|c} 
Character \\
11
\end{tabular} & \begin{tabular}{|c|} 
Character \\
$\mathbf{1 2}$
\end{tabular} & $\begin{array}{c}\text { Character } \\
13\end{array}$ & $\begin{array}{c}\text { Character } \\
14\end{array}$ & $\begin{array}{c}\text { Character } \\
15\end{array}$ & \begin{tabular}{|c|} 
Character \\
16
\end{tabular} & \begin{tabular}{|c|} 
Character \\
17
\end{tabular} & $\begin{array}{c}\text { Character } \\
18\end{array}$ & \begin{tabular}{|c|} 
Character \\
19
\end{tabular} & \begin{tabular}{|c|} 
Character \\
$\mathbf{2 0}$
\end{tabular} & $\begin{array}{c}\text { Character } \\
21\end{array}$ & $\begin{array}{c}\text { Character } \\
\text { 22 }\end{array}$ & $\begin{array}{c}\text { Character } \\
23\end{array}$ & $\begin{array}{c}\text { Character } \\
24\end{array}$ \\
\hline Character 1 & & & & & & & & & & & & & & & & & & & & & & & & \\
\hline Character 2 & $-0.058^{\mathrm{NS}}$ & & & & & & & & & & & & & & & & & & & & & & & \\
\hline Character 3 & $0.046^{\mathrm{NS}}$ & $0.988^{* *}$ & & & & & & & & & & & & & & & & & & & & & & \\
\hline Character 4 & $-0.016^{N S}$ & $0.997^{* * 1}$ & $0.997^{* *}$ & & & & & & & & & & & & & & & & & & & & & \\
\hline Character 5 & \begin{tabular}{|l|}
$0.020^{\mathrm{NS}}$ \\
\end{tabular} & 0.976 & $0.990^{* *}$ & $0.985^{* *}$ & & & & & & & & & & & & & & & & & & & & \\
\hline Character 6 & $0.460^{*}$ & $0.549^{* * *}$ & $0.529^{* *}$ & $0.507^{*}$ & $0.565^{* *}$ & & & & & & & & & & & & & & & & & & & \\
\hline Character 7 & $0.365^{\mathrm{NS}}$ & $-0.106^{\mathrm{NS}}$ & $-0.006^{\mathrm{NS}}$ & $-0.076^{\text {NS }}$ & $0.074^{\mathrm{NS}}$ & $0.251^{\mathrm{NS}}$ & & & & & & & & & & & & & & & & & & \\
\hline Character 8 & \begin{tabular}{|l|}
$-0.397^{\text {NS }}$ \\
\end{tabular} & 0.806 & $0.802^{* *}$ & $0.834^{* *}$ & $0.885^{*}$ & $0.155^{\mathrm{NS}}$ & $0.203^{\mathrm{NS}}$ & & & & & & & & & & & & & & & & & \\
\hline Character 9 & $0.115^{\mathrm{NS}}$ & $1.185^{* * *}$ & $1.190^{* * *}$ & $1.192^{* * *}$ & $1.185^{* *}$ & $0.472^{*}$ & $-0.119^{\mathrm{NS}}$ & $0.814^{* *}$ & & & & & & & & & & & & & & & & \\
\hline $\begin{array}{c}\text { Character } \\
10\end{array}$ & $0.089^{\mathrm{NS}}$ & $0.745^{* * *}$ & $0.731^{* *}$ & $0.739^{* *}$ & $0.822^{* *}$ & $0.912^{* *}$ & $0.413^{*}$ & $0.796^{* *}$ & $0.784^{* *}$ & & & & & & & & & & & & & & & \\
\hline $\begin{array}{c}\text { Character } \\
11\end{array}$ & $0.062^{\mathrm{NS}}$ & $0.941^{* *}$ & $0.921^{* *}$ & $0.938^{* *}$ & $0.969^{* *}$ & $0.740^{* *}$ & $0.118^{\mathrm{NS}}$ & 0.829 & $0.980^{* *}$ & $0.934^{* *}$ & & & & & & & & & & & & & & \\
\hline \begin{tabular}{c|} 
Character \\
12
\end{tabular} & $0.371^{\mathrm{NS}}$ & $0.502^{*}$ & $0.564^{* *}$ & $0.502^{*}$ & $0.593^{* *}$ & $0.872^{* *}$ & $0.507^{*}$ & $0.493^{*}$ & $0.605^{* *}$ & $0.948^{* *}$ & $0.711^{* *}$ & & & & & & & & & & & & & \\
\hline $\begin{array}{c}\text { Character } \\
13\end{array}$ & $-0.759^{* *}$ & $-0.022^{\mathrm{NS}}$ & $-0.030^{\mathrm{NS}}$ & $0.011^{\mathrm{NS}}$ & $0.004^{\mathrm{NS}}$ & $-0.774^{* *}$ & $-0.077^{\mathrm{NS}}$ & $0.494^{*}$ & $0.072^{\mathrm{NS}}$ & $-0.303^{\mathrm{NS}}$ & $-0.143^{\mathrm{NS}}$ & $-0.536^{* *}$ & & & & & & & & & & & & \\
\hline \begin{tabular}{c|} 
Character \\
14
\end{tabular} & $0.432^{*}$ & $0.740^{* *}$ & $0.808^{* *}$ & $0.798^{* *}$ & $0.792^{* *}$ & $0.359^{\mathrm{NS}}$ & $-0.055^{\mathrm{NS}}$ & $0.479^{*}$ & $1.042^{* *}$ & $0.415^{*}$ & $0.670^{* *}$ & $0.473^{*}$ & $-0.139^{\mathrm{NS}}$ & & & & & & & & & & & \\
\hline \begin{tabular}{c|} 
Character \\
15
\end{tabular} & $0.717^{* *}$ & $0.347^{\mathrm{NS}}$ & $0.372^{\mathrm{NS}}$ & $0.330^{\mathrm{NS}}$ & $0.403^{\mathrm{NS}}$ & $0.922^{* * *}$ & $0.423^{*}$ & $-0.028^{\mathrm{NS}}$ & $0.414^{*}$ & $0.569^{* *}$ & 0.502 & $0.658^{* *}$ & $-0.763^{* *}$ & $0.345^{\mathrm{NS}}$ & & & & & & & & & & \\
\hline \begin{tabular}{c|} 
Character \\
16
\end{tabular} & $0.661^{* *}$ & $0.362^{\mathrm{NS}}$ & $0.374^{\mathrm{NS}}$ & $0.339^{\mathrm{NS}}$ & $0.414^{*}$ & $0.995^{* *}$ & $0.402^{\mathrm{NS}}$ & $0.006^{\mathrm{NS}}$ & $0.442^{*}$ & $0.643^{* *}$ & $0.548^{* * *}$ & $0.746^{* *}$ & $-0.820^{* *}$ & $0.315^{\mathrm{NS}}$ & $0.993^{* *}$ & & & & & & & & & \\
\hline $\begin{array}{c}\text { Character } \\
17\end{array}$ & $0.854^{* *}$ & $-0.251^{\mathrm{NS}}$ & $-0.226^{\mathrm{NS}}$ & $-0.264^{\mathrm{NS}}$ & $-0.260^{\mathrm{NS}}$ & $0.516^{* *}$ & $0.102^{\mathrm{NS}}$ & $-0.820^{* *}$ & $-0.227^{\mathrm{NS}}$ & $-0.156^{\mathrm{NS}}$ & $-0.206^{\mathrm{NS}}$ & $0.283^{\mathrm{NS}}$ & $-0.970^{* *}$ & $0.002^{\mathrm{NS}}$ & $0.730^{* * *}$ & $0.697^{* *}$ & & & & & & & & \\
\hline $\begin{array}{c}\text { Character } \\
18\end{array}$ & $-0.533^{* *}$ & $-0.277^{\mathrm{NS}}$ & $-0.307^{\mathrm{Ns}}$ & $-0.265^{\mathrm{NS}}$ & $-0.366^{\mathrm{NS}}$ & $-0.930^{*}$ & $-0.435^{*}$ & $-0.086^{\mathrm{NS}}$ & $-0.287^{\mathrm{NS}}$ & $-0.737^{*}$ & \begin{tabular}{|c|}
$-0.503^{*}$ \\
\end{tabular} & $-0.915^{* * *}$ & 0.740 & $-0.286^{\mathrm{NS}}$ & $-0.829^{* * *}$ & $-0.902^{* *}$ & $-0.559^{* *}$ & & & & & & & \\
\hline \begin{tabular}{c|} 
Character \\
19
\end{tabular} & $-0.593^{* *}$ & $-0.279^{\mathrm{NS}}$. & $-0.311^{\mathrm{NS}}$ & $-0.269^{\mathrm{NS}}$ & $-0.365^{\mathrm{NS}}$ & $-0.945^{* *}$ & $-0.444^{*}$ & $-0.031^{\mathrm{NS}}$ & $-0.298^{\mathrm{NS}}$ & $-0.728^{* *}$ & $-0.501^{*}$ & $-0.917^{* *}$ & $0.795^{* *}$ & $-0.294^{\mathrm{NS}}$ & $-0.865^{* *}$ & $-0.932^{* *}$ & $-0.607^{* *}$ & $1.002^{* *}$ & & & & & & \\
\hline $\begin{array}{c}\begin{array}{c}\text { Character } \\
20\end{array} \\
\end{array}$ & $-0.423^{*}$ & $-0.257^{\mathrm{NS}}$ & $-0.289^{\mathrm{NS}}$ & $-0.247^{\mathrm{NS}}$ & $-0.365^{\mathrm{NS}}$ & $-0.906^{* *}$ & $-0.461^{*}$ & $-0.219^{\mathrm{NS}}$ & $-0.226^{\mathrm{NS}}$ & $-0.843^{* *}$ & $-0.538^{* *}$ & $-0.931^{* *}$ & $0.634^{* *}$ & $-0.273^{\mathrm{NS}}$ & $-0.725^{* *}$ & $-0.835^{* *}$ & $-0.483^{*}$ & $1.009^{* *}$ & $1.001^{* *}$ & & & & & \\
\hline $\begin{array}{c}\text { Character } \\
21\end{array}$ & $-0.558^{* *}-$ & $-0.317^{\mathrm{NS}}$ & $-0.318^{\mathrm{NS}}$ & $-0.285^{\mathrm{NS}}$ & $-0.309^{\mathrm{NS}}$ & $-0.935^{* *}$ & $-0.126^{\mathrm{NS}}$ & $0.103^{\mathrm{NS}}$ & $-0.289^{\mathrm{NS}}$ & $-0.649^{* *}$ & $-0.474^{*}$ & $-0.801^{* *}$ & $0.933^{* *}$ & $-0.287^{\mathrm{NS}}$ & $-0.783^{* *}$ & $-0.869^{* *}$ & $-0.706^{* *}$ & $0.884^{* *}$ & $0.912^{* *}$ & $0.841^{* *}$ & & & & \\
\hline $\begin{array}{c}\text { Character } \\
22\end{array}$ & $-0.453^{*}$ & $-0.309^{\mathrm{NS}}$ & $-0.317^{\mathrm{NS}}$ & $-0.287^{\mathrm{NS}}$ & $-0.359^{\mathrm{NS}}$ & $-0.951^{* *}$ & $-0.283^{\mathrm{NS}}$ & $-0.114^{\mathrm{NS}}$ & $-0.293^{\mathrm{NS}}$ & $-0.819^{* *}$ & $-0.565^{* *}$ & $-0.883^{* *}$ & $0.775^{* *}$ & $-0.271^{\mathrm{NS}}$ & $-0.742^{* *}$ & $-0.850^{* *}$ & $-0.523^{* *}$ & $0.966^{* *}$ & $0.968^{* *}$ & $0.985^{* *}$ & $0.942^{* *}$ & & & \\
\hline \begin{tabular}{c|} 
Character \\
23
\end{tabular} & $-0.416^{*}$ & $-0.306^{\mathrm{NS}}$ & $-0.317^{\mathrm{NS}}$ & $-0.289^{\mathrm{NS}}$ & $-0.385^{\mathrm{NS}}$ & $-0.920^{* *}$ & $-0.399^{\mathrm{NS}}$ & $-0.239^{\mathrm{NS}}$ & $-0.316^{\mathrm{NS}}$ & $-0.902^{* *}$ & $-0.620^{* *}$ & $-0.890^{* *}$ & $0.677^{* *}$ & $-0.269^{\mathrm{NS}}$ & $-0.730^{* *}$ & $-0.831^{* *}$ & $-0.410^{*}$ & $0.959^{* * *}$ & $0.952^{* *}$ & $1.007^{* *}$ & $0.860^{* *}$ & $0.986^{* *}$ & & \\
\hline \begin{tabular}{c|c} 
Character \\
24
\end{tabular} & $0.552^{* *}$ & $0.204^{\mathrm{NS}}$ & $0.226^{\mathrm{NS}}$ & $0.205^{\mathrm{NS}}$ & $0.275^{\mathrm{NS}}$ & $0.834^{* *}$ & $0.218^{\mathrm{NS}}$ & $0.087^{\mathrm{NS}}$ & $0.303^{\mathrm{NS}}$ & $0.730^{* *}$ & $0.520^{* *}$ & $0.763^{* *}$ & $-0.747^{* *}$ & $0.370^{\mathrm{NS}}$ & $0.666^{* *}$ & $0.759^{* *}$ & $0.508^{*}$ & $\mid-0.889^{* *}$ & $-0.888^{* *}$ & $\left|-0.940^{* *}\right|$ & $\mid-0.851^{* *}$ & $-0.947^{* *}$ & $-0.942^{* *} \mid$ & \\
\hline
\end{tabular}

Character 1- percent plant emergence at 30 DAP, 2- plant height at 45 DAP, 3- plant height at 60 DAP, 4- plant height at 75 DAP, 5- plant height at 90 DAP,6- plant vigour at 60 DAP, 7- number of stem per hill, 8- number of leaves per hill, 9- weight of stem per hill, 10- weight of leaves per hill, 11- weight of foliage per hill, 12- leaf area index, 13- number of stomata, 14- foliage senescence at harvest, 15- total yield, 16- marketable yield, 17- harvest index, 18- whitefly population at $10 \mathrm{DAE}, 19$ - whitefly population at $20 \mathrm{DAE}, 20$ - whitefly population at $30 \mathrm{DAE}$, 21 - per cent PALCD at 40 DAP, 22- per cent PALCD at 60 DAP, 23- per cent PALCD at 80 DAP, 24- phenols

*Significant at $5 \%$ level

**Significant at $1 \%$ level 
Table.4 Phenotypic correlation coefficient among different characters in potato

\begin{tabular}{|c|c|c|c|c|c|c|c|c|c|c|c|c|c|c|c|c|c|c|c|c|c|c|c|c|}
\hline & \begin{tabular}{|c|c|} 
Character & C \\
1
\end{tabular} & \begin{tabular}{|c|} 
Characte \\
r 2
\end{tabular} & \begin{tabular}{|c|} 
Character \\
3
\end{tabular} & $\begin{array}{c}\text { Charac } \\
\text { ter } 4\end{array}$ & \begin{tabular}{|c|} 
Character \\
5
\end{tabular} & $\begin{array}{c}\text { Character } \\
6\end{array}$ & $\begin{array}{c}\text { Character } \\
7\end{array}$ & $\begin{array}{c}\text { Character } \\
8\end{array}$ & \begin{tabular}{|c|} 
Character \\
9
\end{tabular} & \begin{tabular}{|c|} 
Character \\
10
\end{tabular} & \begin{tabular}{|c|c|} 
Character \\
11
\end{tabular} & $\begin{array}{c}\text { Character } \\
12\end{array}$ & $\begin{array}{c}\text { Character } \\
13\end{array}$ & $\begin{array}{c}\text { Character } \\
14\end{array}$ & $\begin{array}{c}\text { Character } \\
15\end{array}$ & $\begin{array}{c}\text { Character } \\
16\end{array}$ & $\begin{array}{c}\text { Character } \\
17\end{array}$ & $\begin{array}{c}\begin{array}{c}\text { Character } \\
18\end{array} \\
\end{array}$ & \begin{tabular}{|c|} 
Character C \\
19
\end{tabular} & $\begin{array}{c}\text { Character } \\
\mathbf{2 0}\end{array}$ & $\begin{array}{c}\text { Character } \\
21\end{array}$ & \begin{tabular}{|c|c|c|} 
Characterc \\
22
\end{tabular} & $\begin{array}{c}\text { Character } \\
23\end{array}$ & \begin{tabular}{|c|}
$\begin{array}{c}\text { Characte } \\
\text { r 24 }\end{array}$ \\
\end{tabular} \\
\hline Character 1 & & & & & & & & & & & & & & & & & & & & & & & & \\
\hline Character 2 & $-0.056^{\mathrm{NS}}$ & & & & & & & & & & & & & & & & & & & & & & & \\
\hline Character 3 & $0.041^{\mathrm{Ns}}$ & $0.983^{* *}$ & & & & & & & & & & & & & & & & & & & & & & \\
\hline \begin{tabular}{|l|} 
Character 4 \\
\end{tabular} & $-0.008^{\mathrm{Ns}}$ & $0.988^{* *}$ & $0.992^{*}$ & & & & & & & & & & & & & & & & & & & & & \\
\hline Character 5 & $0.024^{\mathrm{Ns}}$ & $0.968^{* *=}$ & $0.981^{*}$ & $0.982^{*}=$ & & & & & & & & & & & & & & & & & & & & \\
\hline Character 6 & $0.355^{\mathrm{Ns}}$ & $0.482^{*}$ & $0.485^{\circ}$ & $0.456^{*}$ & $0.494^{\circ}$ & & & & & & & & & & & & & & & & & & & \\
\hline \begin{tabular}{|l|} 
Character 7 \\
\end{tabular} & $0.301^{\mathrm{Ns}}$ & $-0.103^{\mathrm{NS}}$ & $-0.004^{\mathrm{NS}}$ & $0.078^{\mathrm{NS}}$ & $0.069^{\mathrm{ss}}$ & $0.268^{\mathrm{NS}}$ & & & & & & & & & & & & & & & & & & \\
\hline \begin{tabular}{|l|} 
Character 8 \\
\end{tabular} & $-0.379^{\mathrm{NS}}$ & $0.620^{* *}$ & $0.628^{*}$ & $0.611^{*}$ & $0.643^{*}$ & $0.292^{\mathrm{NS}}$ & $0.252^{\mathrm{NS}}$ & & & & & & & & & & & & & & & & & \\
\hline Character 9 & $0.052^{\mathrm{NS}}$ & $0.734^{* *}$ & $0.763^{*}$ & $0.769^{* *}$ & $0.746^{*}$ & $0.463^{*}$ & $0.062^{\mathrm{NS}}$ & $0.662^{*}$ & & & & & & & & & & & & & & & & \\
\hline \begin{tabular}{|l|} 
Character 10 \\
\end{tabular} & $-0.033^{\mathrm{NS}}$ & $0.541^{* *}$ & $0.529^{*}$ & $0.502^{*}$ & $0.548^{*}$ & $0.622^{* 4}$ & $0.314^{\mathrm{NS}}$ & $0.650^{*}$ & $0.487^{\circ}$ & & & & & & & & & & & & & & & \\
\hline Character 11 & $-0.010^{\mathrm{NS}}$ & $0.787^{* *}$ & $0.780^{*}$ & $0.773^{*}$ & $0.788^{*}$ & $0.638^{* 2+1}$ & $0.157^{\mathrm{ss}}$ & $0.746^{*}$ & $0.787^{*}$ & $0.894^{*}$ & & & & & & & & & & & & & & \\
\hline Character 12 & $0.384^{\mathrm{NS}}$ & $0.463^{*}$ & $0.511^{2}$ & $0.472^{*}$ & $0.563^{*}$ & $0.675^{* *}$ & $0.427^{4}$ & $0.186^{\mathrm{NS}}$ & $0.279^{\mathrm{Ns}}$ & $0.404^{\mathrm{NS}}$ & $0.404^{\mathrm{Ns}}$ & & & & & & & & & & & & & \\
\hline Character 13 & $-0.655^{*}$ & $-0.012^{\mathrm{NS}}$ & $-0.023^{\mathrm{NS}}$ & $0.007^{\mathrm{NS}}$ & $0.017^{\mathrm{Ns}}$ & $-0.688^{4}$ & $-0.078^{\mathrm{NS}}$ & $0.369^{\mathrm{NS}}$ & $-0.064^{\mathrm{Ns}}$ & $-0.179^{\mathrm{NS}}$ & $-0.127^{\mathrm{Ns}}$ & $-0.498^{\circ}$ & & & & & & & & & & & & \\
\hline Character 14 & $0.413^{*}$ & $0.727^{* *}$ & $0.798^{*}$ & $0.786^{* *}$ & $0.778^{*}$ & $0.320^{\mathrm{NS}}$ & $-0.060^{\mathrm{NS}}$ & $0.372^{\mathrm{NS}}$ & $0.650^{*}$ & $0.273^{\mathrm{NS}}$ & $0.547^{*}$ & $0.434^{\circ}$ & $-0.124^{\mathrm{NS}}$ & & & & & & & & & & & \\
\hline Character 15 & $0.629^{*}$ & $0.332^{\mathrm{NS}}$ & $0.354^{\mathrm{NS}}$ & $0.319^{\mathrm{NS}}$ & $0.372^{\mathrm{NS}}$ & $0.780^{* 2}$ & $0.338^{\mathrm{NS}}$ & $-0.062^{\mathrm{NS}}$ & $0.266^{\mathrm{NS}}$ & $0.436^{\circ}$ & $0.441^{\prime}$ & $0.570^{*}$ & $-0.728^{*}$ & $0.336^{\mathrm{NS}}$ & & & & & & & & & & \\
\hline Character 16 & $0.580^{*}$ & $0.343^{\mathrm{NS}}$ & $0.356^{\mathrm{NS}}$ & $0.318^{\mathrm{NS}}$ & $0.371^{\mathrm{NS}}$ & $0.826^{* 4}$ & $0.303^{\mathrm{NS}}$ & $-0.026^{\mathrm{NS}}$ & $0.213^{\mathrm{NS}}$ & $0.523^{*}$ & $0.479^{\circ}$ & $0.607^{*}$ & $-0.742^{*}$ & $0.309^{\mathrm{NS}}$ & $0.975^{*}$ & & & & & & & & & \\
\hline Character 17 & $0.701^{*}$ & $-0.224^{\mathrm{NS}}$ & $-0.195^{\mathrm{NS}}$ & $0.244^{\mathrm{NS}}$ & $-0.244^{\mathrm{NS}}$ & $0.431^{*}$ & $0.077^{\mathrm{NS}}$ & $-0.580^{*}$ & $-0.265^{\mathrm{NS}}$ & $-0.075^{\mathrm{NS}}$ & $-0.179^{\mathrm{NS}}$ & $0.226^{\mathrm{NS}}$ & $-0.791^{*}$ & $0.007^{\mathrm{NS}}$ & $0.624^{*}$ & $0.639^{* 4}$ & & & & & & & & \\
\hline Character 18 & $-0.472^{2}$ & $-0.274^{\mathrm{NS}}$ & $-0.302^{\mathrm{NS}}$ & $0.259^{\mathrm{NS}}$ & $-0.357^{\mathrm{NS}}$ & $-0.831^{* 4}$ & $-0.421^{\prime}$ & $-0.061^{\mathrm{NS}}$ & $-0.173^{\mathrm{NS}}$ & $-0.486^{\circ}$ & $-0.402^{\mathrm{NS}}$ & $-0.858^{* 4}$ & $0.707^{* 4}$ & $-0.284^{\mathrm{NS}}$ & $-0.782^{*}$ & $-0.835^{* 4}$ & $-0.511^{*}$ & & & & & & & \\
\hline Character 19 & $-0.503^{3}$ & $-0.281^{\mathrm{NS}}$ & $-0.312^{\mathrm{NS}}$ & $0.258^{\mathrm{NS}}$ & $-0.345^{\mathrm{Ns}}$ & $-0.849^{* *+}$ & $-0.417^{*}$ & $-0.060^{\mathrm{NS}}$ & $-0.176^{\mathrm{NS}}$ & -0.476 & $-0.397^{\mathrm{NS}}$ & $-0.837^{*}$ & $0.734^{*}$ & $-0.288^{\mathrm{NS}}$ & $-0.812^{*}$ & $-0.856^{* 4}$ & $-0.568^{* *+}$ & $0.983^{*}$ & & & & & & \\
\hline Character 20 & $-0.408^{\prime}$ & $-0.234^{\mathrm{NS}}$ & $-0.262^{\mathrm{NS}}$ & $0.232^{\mathrm{NS}}$ & $-0.336^{\mathrm{NS}}$ & $-0.724^{4}$ & $-0.419^{*}$ & $-0.102^{\mathrm{NS}}$ & $-0.205^{\mathrm{NS}}$ & $-0.454^{*}$ & $-0.386^{\mathrm{NS}}$ & $-0.853^{*}$ & $0.616^{* 4}$ & $-0.261^{\mathrm{NS}}$ & $-0.656^{* *}$ & $-0.691^{* 4}$ & $-0.282^{\mathrm{NS}}$ & $0.928^{* 4}$ & $0.889^{54}$ & & & & & \\
\hline Character 21 & $-0.521^{*}$ & $-0.315^{\mathrm{NS}}$ & $-0.318^{\mathrm{NS}}$ & $0.280^{\mathrm{NS}}$ & $-0.301^{\mathrm{Ns}}$ & $-0.867^{4 *}$ & $-0.134^{\mathrm{NS}}$ & $0.046^{\mathrm{NS}}$ & $-0.214^{\mathrm{NS}}$ & $-0.437^{\circ}$ & $-0.393^{\mathrm{NS}}$ & $-0.743^{*}$ & $0.875^{* 4}$ & $-0.286^{\mathrm{NS}}$ & $-0.737^{* 4}$ & $-0.802^{* 4}$ & $-0.627^{* 4}$ & $0.874^{54}$ & $0.892^{* \prime}$ & $0.784^{* 4}$ & & & & \\
\hline Character 22 & $-0.404^{\mathrm{NS}}$ & $-0.303^{\mathrm{NS}}$ & $-0.305^{\mathrm{NS}}$ & $0.277^{\mathrm{NS}}$ & $-0.346^{\mathrm{NS}}$ & $-0.861^{*+}$ & $-0.264^{\mathrm{NS}}$ & $-0.103^{\mathrm{NS}}$ & $-0.216^{\mathrm{NS}}$ & $-0.553^{*}$ & $-0.475^{*}$ & $-0.826^{*}$ & $0.753^{*}$ & $-0.268^{\mathrm{NS}}$ & $-0.711^{*}$ & $-0.785^{* 4}$ & $-0.453^{*}$ & $0.948^{* 4}$ & $0.933^{*}$ & $0.909^{*}$ & $0.923^{* 4}$ & & & \\
\hline Character 23 & $-0.371^{\mathrm{NS}}$ & $-0.300^{\mathrm{NS}}$ & $-0.314^{\mathrm{NS}}$ & $0.286^{\mathrm{NS}}$ & $-0.379^{\mathrm{NS}}$ & $-0.855^{* *+}$ & $-0.380^{\mathrm{NS}}$ & $-0.202^{\mathrm{NS}}$ & $-0.231^{\mathrm{Ns}}$ & $-0.615^{*}$ & $-0.523^{*}$ & $-0.826^{*}$ & $0.642^{*}$ & $-0.263^{\mathrm{Ns}}$ & $-0.685^{* 4}$ & $-0.764^{* 4}$ & $-0.357^{\mathrm{NS}}$ & $0.944^{*}$ & $0.922^{2}$ & $0.919^{*}$ & $0.853^{* 4}$ & $0.972^{2}$ & & \\
\hline Character 24 & $0.517^{*}$ & $0.198^{\mathrm{NS}}$ & $0.218^{\mathrm{NS}}$ & $0.205^{\mathrm{NS}}$ & $0.275^{\mathrm{Ns}}$ & $0.728^{* *}$ & $0.188^{\mathrm{NS}}$ & $0.005^{\mathrm{NS}}$ & $0.132^{\mathrm{NS}}$ & $0.456^{\circ}$ & $0.384^{\mathrm{NS}}$ & $0.735^{*}$ & $-0.685^{\prime \prime}$ & $0.366^{\mathrm{NS}}$ & $0.621^{4}$ & $0.695^{* 4}$ & $0.452^{*}$ & $-0.874^{* *}$ & $-0.843^{24}$ & $-0.855^{*}$ & $-0.828^{* * *}$ & $-0.921^{*}$ & $-0.925^{*}$ & \\
\hline
\end{tabular}


Table.5 Direct (diagonal) and indirect (off- diagonal ) path coefficients of different characters in potato

\begin{tabular}{|c|c|c|c|c|c|c|c|c|c|c|c|c|c|c|c|c|c|c|c|c|c|c|c|c|}
\hline & $\begin{array}{c}\text { Character } \\
1\end{array}$ & $\underset{2}{\text { Character }}$ & $\begin{array}{c}\text { Character } \\
\mathbf{3}\end{array}$ & $\begin{array}{c}\text { taracte } \\
4\end{array}$ & $\begin{array}{c}\text { aaracter } \\
5\end{array}$ & haracter & $\begin{array}{c}\text { haracter } \\
7\end{array}$ & $\begin{array}{c}\text { Character } \\
8\end{array}$ & $\begin{array}{c}\text { Character } \\
9\end{array}$ & $\begin{array}{c}\text { Character } \\
10\end{array}$ & $\begin{array}{c}\text { Character } \\
11\end{array}$ & $\underset{12}{\text { Character }}$ & $\underset{13}{\text { Character }}$ & $\begin{array}{l}\text { haracter } \\
14\end{array}$ & $\begin{array}{c}\text { Character } \\
15\end{array}$ & $\begin{array}{c}\text { Character } \\
16\end{array}$ & $\underset{17}{\text { Character }}$ & $\begin{array}{c}\text { Character } \\
18\end{array}$ & 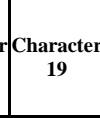 & $\begin{array}{c}\text { haracter } \\
\mathbf{2 0}\end{array}$ & $\underset{21}{\text { Character }}$ & $\begin{array}{c}\text { haracter } \\
22\end{array}$ & Character & \begin{tabular}{|c|c} 
reg with \\
PALCD \\
at 80 \\
DAP \\
\end{tabular} \\
\hline character 1 & $\underline{0.036}$ & -0.108 & 0.088 & -0.013 & -0.085 & -0.015 & 0.297 & 0.272 & 0.040 & 0.009 & -0.047 & -0.435 & -0.693 & 0.061 & 0.137 & -0.145 & -0.055 & 0.290 & -0.425 & -0.058 & -0.328 & 0.841 & -0.037 & $-0.416^{*}$ \\
\hline Character 2 & -0.002 & 1.856 & 1.919 & 0.784 & -4.053 & -0.017 & -0.086 & -0.552 & 0.410 & 0.079 & -0.717 & -0.589 & -0.020 & 0.105 & 0.066 & -0.079 & 0.016 & 0.151 & -0.200 & -0.036 & -0.186 & 0.574 & -0.014 & $-0.306^{\mathrm{NS}}$ \\
\hline Character 3 & 0.002 & 1.835 & 1.941 & 0.784 & -4.110 & -0.017 & -0.005 & -0.550 & 0.412 & 0.078 & -0.702 & -0.661 & -0.028 & 0.115 & 0.071 & -0.082 & 0.014 & 0.167 & -0.223 & -0.040 & -0.187 & 0.587 & -0.015 & $-0.317^{\mathrm{NS}}$ \\
\hline character 4 & -0.001 & 1.851 & 1.936 & $\underline{0.786}$ & -4.089 & -0.016 & -0.061 & -0.571 & 0.413 & 0.079 & -0.714 & -0.588 & 0.010 & 0.113 & 0.063 & -0.074 & 0.017 & 0.144 & -0.193 & -0.034 & -0.168 & 0.532 & -0.014 & $-0.289^{\mathrm{NS}}$ \\
\hline Character 5 & 0.001 & 1.812 & 1.922 & 0.774 & -4.152 & -0.018 & 0.060 & -0.606 & 0.410 & 0.087 & -0.738 & -0.695 & 0.004 & 0.112 & 0.077 & -0.091 & 0.017 & 0.199 & -0.262 & -0.050 & -0.182 & 0.667 & -0.018 & $-0.385^{\mathrm{NS}}$ \\
\hline character 6 & 0.016 & 1.020 & 1.028 & 0.399 & -2.347 & -0.032 & 0.204 & -0.106 & 0.163 & 0.097 & -0.564 & -1.022 & -0.706 & 0.051 & 0.176 & -0.218 & -0.033 & 0.507 & -0.677 & -0.125 & -0.549 & 1.765 & -0.056 & $-0.920^{* *}$ \\
\hline Character 7 & 0.013 & -0.197 & -0.011 & -0.060 & -0.308 & -0.008 & $\underline{0.812}$ & -0.139 & -0.041 & 0.044 & -0.090 & -0.594 & -0.071 & -0.008 & 0.081 & -0.088 & -0.007 & 0.237 & -0.318 & -0.064 & -0.074 & 0.524 & -0.015 & $-0.399^{\mathrm{NS}}$ \\
\hline Character 8 & -0.014 & 1.496 & 1.558 & 0.655 & -3.673 & -0.005 & 0.165 & $-\underline{-0.686}$ & 0.282 & 0.085 & -0.631 & -0.577 & 0.451 & 0.068 & -0.005 & -0.001 & 0.052 & 0.047 & -0.022 & -0.030 & 0.061 & 0.211 & -0.006 & $-0.239^{\mathrm{NS}}$ \\
\hline character 9 & 0.004 & 2.200 & 2.310 & 0.937 & -4.919 & -0.015 & -0.097 & -0.558 & $\underline{0.346}$ & 0.083 & -0.746 & -0.709 & 0.066 & 0.148 & 0.079 & -0.097 & 0.015 & 0.157 & -0.213 & -0.031 & -0.170 & 0.544 & -0.020 & $-0.316^{\mathrm{NS}}$ \\
\hline Character 10 & 0.003 & 1.383 & 1.418 & 0.581 & -3.411 & -0.029 & 0.335 & -0.546 & 0.271 & $\underline{0.106}$ & -0.711 & -1.111 & -0.277 & 0.059 & 0.108 & -0.141 & 0.010 & 0.401 & -0.521 & -0.116 & -0.381 & 1.520 & -0.049 & $-0.902^{* *}$ \\
\hline Character 11 & 0.002 & 1.748 & 1.789 & 0.737 & -4.024 & -0.023 & 0.096 & -0.568 & 0.339 & 0.099 & $\underline{-0.762}$ & -0.833 & -0.131 & 0.095 & 0.096 & -0.120 & 0.013 & 0.274 & -0.359 & -0.074 & -0.279 & 1.049 & -0.035 & $-0.620^{*}$ \\
\hline Character 12 & 0.013 & 0.933 & 1.095 & 0.395 & -2.462 & -0.028 & 0.411 & -0.338 & 0.209 & 0.101 & -0.542 & -1.172 & -0.490 & 0.067 & 0.125 & -0.164 & -0.018 & 0.498 & -0.657 & -0.129 & -0.471 & 1.638 & -0.051 & $-0.890^{\circ *}$ \\
\hline Character 13 & -0.027 & -0.041 & -0.059 & 0.009 & -0.018 & 0.025 & -0.063 & -0.339 & 0.025 & -0.032 & 0.109 & 0.629 & $\underline{0.913}$ & -0.020 & -0.145 & 0.180 & 0.062 & -0.403 & 0.570 & 0.088 & 0.548 & -1.438 & 0.050 & $0.677^{* *}$ \\
\hline Character 14 & 0.015 & 1.374 & 1.569 & 0.627 & -3.290 & -0.011 & -0.044 & -0.328 & 0.361 & 0.044 & -0.510 & -0.554 & -0.127 & $\underline{0.142}$ & 0.066 & -0.069 & 0.000 & 0.156 & -0.210 & -0.038 & -0.169 & 0.503 & -0.025 & $-0.269^{\mathrm{NS}}$ \\
\hline Character 15 & 0.026 & 0.644 & 0.722 & 0.259 & -1.674 & -0.029 & 0.343 & 0.019 & 0.143 & 0.061 & -0.382 & -0.771 & -0.697 & 0.049 & $\underline{0.190}$ & -0.218 & -0.047 & 0.452 & -0.620 & -0.100 & -0.461 & 1.376 & -0.044 & $-0.730^{* *}$ \\
\hline Character 16 & 0.024 & 0.672 & 0.727 & 0.266 & -1.718 & -0.032 & 0.327 & -0.004 & 0.153 & 0.068 & -0.418 & -0.874 & -0.749 & 0.045 & 0.189 & $\underline{-0.219}$ & -0.045 & 0.491 & -0.668 & -0.115 & -0.511 & 1.578 & -0.051 & $-0.831^{*}$ \\
\hline Character 17 & 0.030 & -0.466 & -0.439 & -0.208 & 1.079 & -0.016 & 0.082 & 0.562 & -0.078 & -0.017 & 0.157 & -0.332 & -0.886 & 0.000 & 0.139 & -0.153 & -0.064 & 0.305 & -0.435 & -0.067 & -0.415 & 0.971 & -0.034 & $-0.410^{*}$ \\
\hline Character 18 & -0.019 & -0.515 & -0.596 & -0.208 & 1.520 & 0.029 & -0.353 & 0.059 & -0.099 & -0.078 & 0.383 & 1.072 & 0.676 & -0.041 & \begin{tabular}{|l|}
-0.158 \\
\end{tabular} & 0.198 & 0.036 & $\underline{-0.545}$ & 0.718 & 0.139 & 0.520 & -1.792 & 0.059 & $0.959^{* \prime}$ \\
\hline Character 19 & -0.021 & -0.518 & -0.605 & -0.212 & 1.517 & 0.030 & -0.360 & 0.021 & -0.103 & -0.077 & 0.381 & 1.075 & 0.726 & -0.042 & \begin{tabular}{|l}
-0.165 \\
\end{tabular} & 0.204 & 0.039 & -0.546 & $\underline{0.717}$ & 0.138 & 0.536 & -1.797 & 0.059 & $0.952^{* \prime}$ \\
\hline Character 20 & -0.015 & -0.478 & -0.560 & -0.195 & 1.514 & 0.029 & -0.374 & 0.150 & -0.078 & -0.090 & 0.410 & 1.091 & 0.579 & -0.039 & -0.138 & 0.183 & 0.031 & -0.550 & 0.718 & $\underline{0.138}$ & 0.494 & -1.827 & 0.063 & $1.007^{* \prime}$ \\
\hline Character 21 & -0.020 & -0.588 & -0.618 & -0.224 & 1.283 & 0.030 & -0.102 & -0.071 & -0.100 & -0.069 & 0.361 & 0.939 & 0.852 & -0.041 & \begin{tabular}{|l|l|} 
& -0.149 \\
\end{tabular} & 0.190 & 0.045 & -0.482 & 0.654 & 0.116 & 0.588 & -1.748 & 0.057 & $0.860^{*}$ \\
\hline Character 22 & -0.016 & -0.574 & -0.615 & -0.225 & 1.492 & 0.030 & -0.229 & 0.078 & -0.101 & -0.087 & 0.431 & 1.035 & 0.708 & -0.038 & -0.141 & 0.186 & 0.033 & -0.526 & 0.694 & 0.136 & 0.554 & $\underline{-1.855}$ & 0.063 & $0.986^{*}$ \\
\hline Character 24 & 0.019 & 0.379 & 0.439 & 0.161 & -1.142 & -0.026 & 0.177 & -0.060 & 0.105 & 0.078 & -0.396 & -0.894 & -0.682 & 0.053 & 0.127 & -0.166 & -0.032 & 0.484 & -0.636 & -0.130 & -0.500 & 1.757 & -0.067 & \\
\hline
\end{tabular}

Character 1- percent plant emergence at 30 DAP, 2- plant height at 45 DAP, 3- plant height at 60 DAP, 4- plant height at 75 DAP, 5- plant height at 90 DAP,6- plant vigour at 60 DAP, 7- number of stem per hill, 8- number of leaves per hill, 9- weight of stem per hill, 10- weight of leaves per hill, 11- weight of foliage per hill, 12- leaf area index, 13- number of stomata, 14- foliage senescence at harvest, 15- total yield, 16- marketable yield, 17- harvest index, 18- whitefly population at 10 DAE, 19- whitefly population at 20 DAE, 20- whitefly population at 30 DAE, 21 - per cent PALCD at 40

DAP, 22- per cent PALCD at 60 DAP, 23- per cent PALCD at 80 DAP, 24- phenols

*Significant at 5\% level

**Significant at $1 \%$ level 
It is concluded on the basis of correlation studies that per cent PALCD incidence was significantly and positively associated with whitefly population and number of stomata per leaf, which indicates that for improving disease resistance, selection should be made for those lines which have less number of whitefly and number of stomata. Per cent PALCD incidence was significant and negatively associated with plant height, plant vigour, weight of stem per hill, weight of leaves per hill, weight of foliage per hill, LAI, total yield, marketable yield, harvest index and phenols which suggests that for PALCD resistance, selection should be made on the basis of high values of these characters. Path analysis revealed that per cent PALCD incidence had positive and highest contribution (1.266) towards plant height at 45 DAP. Positive and direct contribution of foliage senescence, harvest index, number of stems per hill, number of whitefly at 30 DAE towards PALCD incidence was also observed. Highest indirect contribution was exhibited by plant height at 90 DAE (2.395).

\section{References}

Allard, R.W. 1960. Principles of Plant Breeding, John Wiley and Sons Inc., New York, USA.

Anonymous. 2011a. Area and production of vegetable Crops in Haryana during 2010-11. Directorate of Horticulture, Punchkula, Govt. of Haryana.

Anonymous. 2011b. Directorate of Economics and statistics, during 201011. Ministry of Agriculture, Potato in India, Govt. of India FAOSTAT at 3. FAO. Org.

Ara, T., Hayder, A., Islam, M. A., Azad, M. A. and Khokan, E.: Path analysis in potato. J. Soil Nature, 3(2): 20-23.

Bhardwaj, N.V. and Sharma, J.A. 2005. Genetic parameters and character association in tomato. Bangladesh J. Agric. Res., 30(1): 49-56.
Bhullar, B.S., Bajaj, K. and Bhatia, J.S. 1972. Studies on the phenols of resistance and susceptibile varities of chillies in relation to anthracnose disease. Phytopathol. Z., 58: 1255-1260.

Borah, R.K. and Bardoloi, D.K. 1998. Influence on planting time on the incidence of leaf-curl virus disease and whitefly population on tomato. Indian J. Virol., 14(1): 71-73.

Burton, G.M. 1952. Quantitative inheritance in grasses. In: Proceedings of the 6th International Grassland Congress, 1: 277-283.

Dewey, D.R. and Lu, K.H. 1959. A correlation and path coefficient analysis of components of created wheat grass seed production. Agron. J., 51: 515-518.

Garg, I.D., Kumar, S., Khurana, S.M.P. and Lakra, B.S. 2001. Association of geminivirus with potato apical leaf curl in India and its immuno-electron microscopic detection. J. Indian Potato Assoc., 28(2-4): 227-232.

Johnson, H.W., Robinson, H.F. and Comstoc, R.E.K. 1995. Estimation of genetic and environmental variability in soybean. Agron. J., 47: 314-318.

Khayatnezhad, M., Shahriari, R., Gholamin, R., Shahzad, J.S. and Roghayyeh, Z.M. 2001. Correlation and path analysis between yield and yield components in potato (Solanum tubersum L.) Middle East J. Scientific Res., 7(1): 17-21.

Khurana, S.M.P. 1999. Potato viruses and viral diseases. Tech. Bull. No. 35(Revised), CPRI, Shimla, 94 p.

Lakra, B.S. 2002. Leaf-curl: A threat to potato crop in Haryana. J. Myco. Pl. Pathol., 32: 367.

Lakra, B.S. 2003a. Potato apical leaf-curl begomovirus- symptom, appraisal of a scale and losses in potato crop. J. Indian Potato Assoc., 30(1-2): 119-120.

Lush, J.L. 1949. Heritability of quantitative character in farm animals. In; Proc. of 
the 8th Congr. Genet. Heredities, pp. 356-75.

Mondal, M.A.A. 2003. Improvement of potato (Solanum tuberosum L.) through hybridization and in vitro culture technique. Ph.D. Thesis, Rajshahi University, Rajshahi, Bangladesh.

Panse, V.G. and Sukhatme, P.V. 1995. Statistical Methods for Agricultural Workers. ICAR Publication, New Delhi, India.
Sattar, M.A., Sultana, N., Hossain, M., Rashid, M.H., Islam, A.K. 2007. Genetic variability, correlation and path analysis and potato (Solanum tuberosum L.). Bangladesh J. Pl. Breed. Genet., 20(1): 33-38.

Som, M.G. 1973. Studies on the inheritance of resistance to leaf-curl virus in tomato (Lycopersicon esculentum). Ph.D. Thesis, IARI, New Delhi, India.

\section{How to cite this article:}

Devashri Maan, A.K. Bhatia and Mandeep Rathi. 2017. Correlation Studies on Association of Morphological and Biochemical Traits for Potato Apical Leaf-Curl Disease Resistance or Susceptibility. Int.J.Curr.Microbiol.App.Sci. 6(5): 759-775.

doi: https://doi.org/10.20546/ijcmas.2017.605.086 